\title{
Measurement of Temperature Fields in Methal Hydride Storage Container
}

Tomáš Brestovič, Natália Jasminská, Marián Lázár, L’ubica Kapustová

Faculty of Mechanical Engineering, TU Košice, Department of Power Engineering, Vysokoškolská 4, 04200 Košice, Slovak Republic. E-mail: tomas.brestovic@tuke.sk, natalia.jasminska@tuke.sk, marian.lazar@tuke.sk, lubica.kapustova@tuke.sk

The article analyses the measurement with increased absorption kinetics of hydrogen into the La0.85 $\mathrm{Ce} 0.15 \mathrm{Ni} 5$ alloy. Within a time interval of $180 \mathrm{~s}$ an amount of $0.142 \mathrm{~kg}\left(1.58 \mathrm{~m}^{3}\right)$ of hydrogen was absorbed into $56 \mathrm{~kg}$ of alloy. The process of absorption was accompanied by an increased temperature of the bed. Therefore it was simultaneously cooled by a cooler using Peltier elements. The numerical calculation of non-stationary heat transfer within the bed was performed with a known amount of heat generated in the bed, known temperatures and flow rates. Simulation results allow us to determine temperature time paths at key points of the bed and give insight on the transient phenomena which occurs in the extreme load of the metal hydride (MH) bed. The temperature field is analyzed for different values of thermal conductivity, view of its change during the lifetime of metal hydride. This allows establishing safe limits for the absorption of hydrogen into a particular alloy.

Keywords: Measurement, temperature field, numerical simulation, Ansys CFX, metalhydride, hydrogen.

\section{Acknowledgments}

This paper was written with the financial support of the granting agency KEGA of the Ministry of Education of the Slovak Republic within the project solution No. 041TUKE-4/2013, of the granting agency VEGA of the Ministry of Education of the Slovak Republic within the project solution No. 1/0686/13.

\section{References}

[1] HA, M. Y., KIM, I. K., SONG, H. D., SUNG, S., LEE, D. H. (2004). A numerical study of thermo-fluid phenomena in metal hydride beds in the hydriding process, Int J Heat and Mass Transfer, 47, pp. 2901-2912.

[2] JASMINSKÁ, N., BRESTOVIČ, T., PUŠKÁR, M., GREGA, R., RAJZINGER, J., KORBA, J. (2014). Evaluation of hydrogen storage capacities on individual adsorbents, Measurement, No. 56, pp. 219-230.

[3] GONDÁR, E., SEJČ, P., SCHREK, A. (2015). The Influence of High Temperature Loading on the Structure of Fine Al Powder Compacts, Manufacturing Technology. Vol. 15, No. 1, pp. 35-41.

[4] YONG, L., YUXIN, Z., YUFEI, C., XUEPING, Z., RUIZHU, Z. (2015). The Influence of High Temperature Loading on the Structure of Fine Al Powder Compacts, Manufacturing Technology. Vol. 15, No. 2, pp. $170-176$.

[5] MLYNÁR, P., MASARYK, M. (2012). Optimalization of absortioption cooling unit, Gépeszet, $8^{\text {th }}$ International conference of Mechanical Engineering, BME Budapest, pp. 361-365.

[6] RAJZINGER, J. (2012). Calculation of maximum water content in various natural gases by using modified PengRobinson equation of state, Communications, 14, 4A, pp.29-35.

[7] MICHALEC, Z., TARABA, B., BOJKO, M., KOZUBKOVÁ, M. (2010). CFD modelling of the low-temperature oxidation of coal. Archivum Combustions, Vol. 30, No. 3, pp.133 - 144.

[8] PYSZKO, R., PŘÍHODA, M., VELIČKA, M. (2010). Method for determining the thermal boundary condition in the CC mould for numeric models, Proceedings of 19. conference METAL 2010, pp. 7.

[9] BRESTOVIČ, T., JASMINSKÁ, N., ČARNOGURSKÁ, M., PUŠKÁR, M., KELEMEN, M., FILO, M. (2014). Measuring of thermal characteristics for Peltier thermopile using calorimetric method, Measurement, 53, pp. 4048

[10]BRESTOVIČ, T., JASMINSKÁ, N., PYSZKO, R., LÁZÁR, M., PUŠKKÁR, M. (2015). Measurement of boundary conditions for numerical solution of temperature fields of metal hydride containers, Measurement. Vol. 72, pp. 5260 . 